\title{
THE TRANSPORT SERVICE OF SMALL TOWNS
}

\author{
Jozef Gnap ${ }^{1, *}$, Jana Kupčuljaková1, L’ubomír Černický1, Grzegorz Dydkowski² \\ ${ }^{1}$ Department of Road and Urban Transport, Faculty of Operation and Economics of Transport and Communications, \\ University of Zilina, Zilina, Slovakia \\ ${ }^{2}$ Department of Transport, University of Economics in Katowice, Katowice, Poland
}

*E-mail of corresponding author: jozef.gnap@fpedas.uniza.sk

\begin{abstract}
Resume
The paper is focused on assessment of the transport services in small towns. Current legislation in the Slovak Republic, however, does not clearly determine which cities must provide the urban public transport (UPT). Analysis of the current state of the UPT evaluated 71 district towns of the SR and it was found out that 21 towns did not provide operation of the UPT. Another criterion for evaluation was the number of inhabitants of the city over 10,000 in Slovakia and selected regions of the Czech Republic and Poland. The paper presents results of a research conducted in the area of a transport operation, along with a proposal for the content of the methodology, based on a multi-criterial analysis to assess the need to introduce the UPT. The EU research results, regarding dependency of a GDP size and transport performances in UPT in selected EU states, Switzerland and Norway, are presented, as well.
\end{abstract}

Available online: https://doi.org/10.26552/com.C.2021.1.A21-A31

\section{Article info}

Received 3 April 2020

Accepted 18 June 2020

Online 23 October 2020

\section{Keywords:}

urban public transport, transport operation plan, UPT accessibility, multi-criterial analysis

ISSN 1335-4205 (print version)

ISSN 2585-7878 (online version)

\section{Introduction}

In the Slovak Republic (SR), the transport operation plans are required to be prepared by the Act on road transport and the Act on transport on the railways in towns, which nowadays act as an order party of the urban public transport. The transport operation plan is a source for granting the transport licences to the UPT lines, for making contracts on transport services in public interest and for drawing up schedules. However, the applicable law in the EU does not specify which towns must have and order UPT. The EU has committed to reduce the air pollution from transport in towns; however, it has not set even minimum requirements for obligation to establish the UPT in towns, e.g. depending on the number of their residents. The EU supports the UPT infrastructure through structural funds, but it does not interfere in the legislation of states in that sense which towns shall provide UPT and to what extent. In the SR, there exists a whole series of district towns (or other towns) with a significant railway station or stop, which is also part of an integrated transport system without any UPT in the town. Thus, in majority of cases the area or time accessibility is not provided. The issue of accessibility, mainly in suburban areas, is for example dealt with in [1].

This paper presents results from research projects for towns and the main goal of the paper was to assess the UPT accessibility in all the district towns of the SR and in some regions of Poland and the Czech Republic, neighbouring with the SR. In addition, the objective was to propose a methodology to determine the need for the UPT based on a multi-criterial analysis.

Within the SR, there is a lag behind in building the integrated transport systems, one reason for which is the non-existence of a law on public passenger transport and a disunity of ordering the urban public transport [2-4].

\section{Analysis of the current state in the Slovak Republic and abroad}

Analysis of the current state of the UPT was evaluated in 71 district towns of the SR and it was found that 21 towns (29\%) did not provide operation of the UPT (Figure 1, left). Out of 50 towns with the UPT, only 12 operators are members of the Association of operators of the public transport for people in conurbations of the Slovak Republic (Figure 1, right).

A duty to operate UPT is neither defined by the law, nor specified exactly. The literature states that in the case of an average transport distance of $2 \mathrm{~km}$ it is possible to use calculations to find out that public transport is desirable when the number of residents of an urban settlement exceeds 15,000 people [5-6]. Considering this fact, it was found that in two district towns (Pezinok and Senec) the number of residents significantly exceeds the required limit. In one town (Detva), the number of residents approaches that limit (Figure 2). 


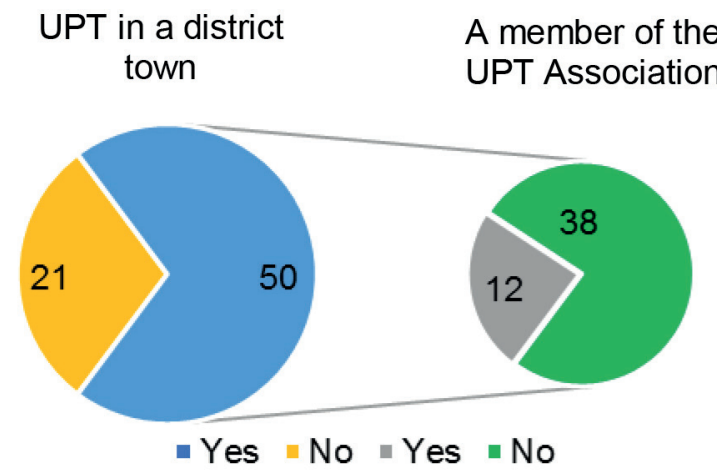

Figure 1 The UPT in district towns (left); members of the Association of operators of the public transport for people in conurbations of the Slovak Republic (right)

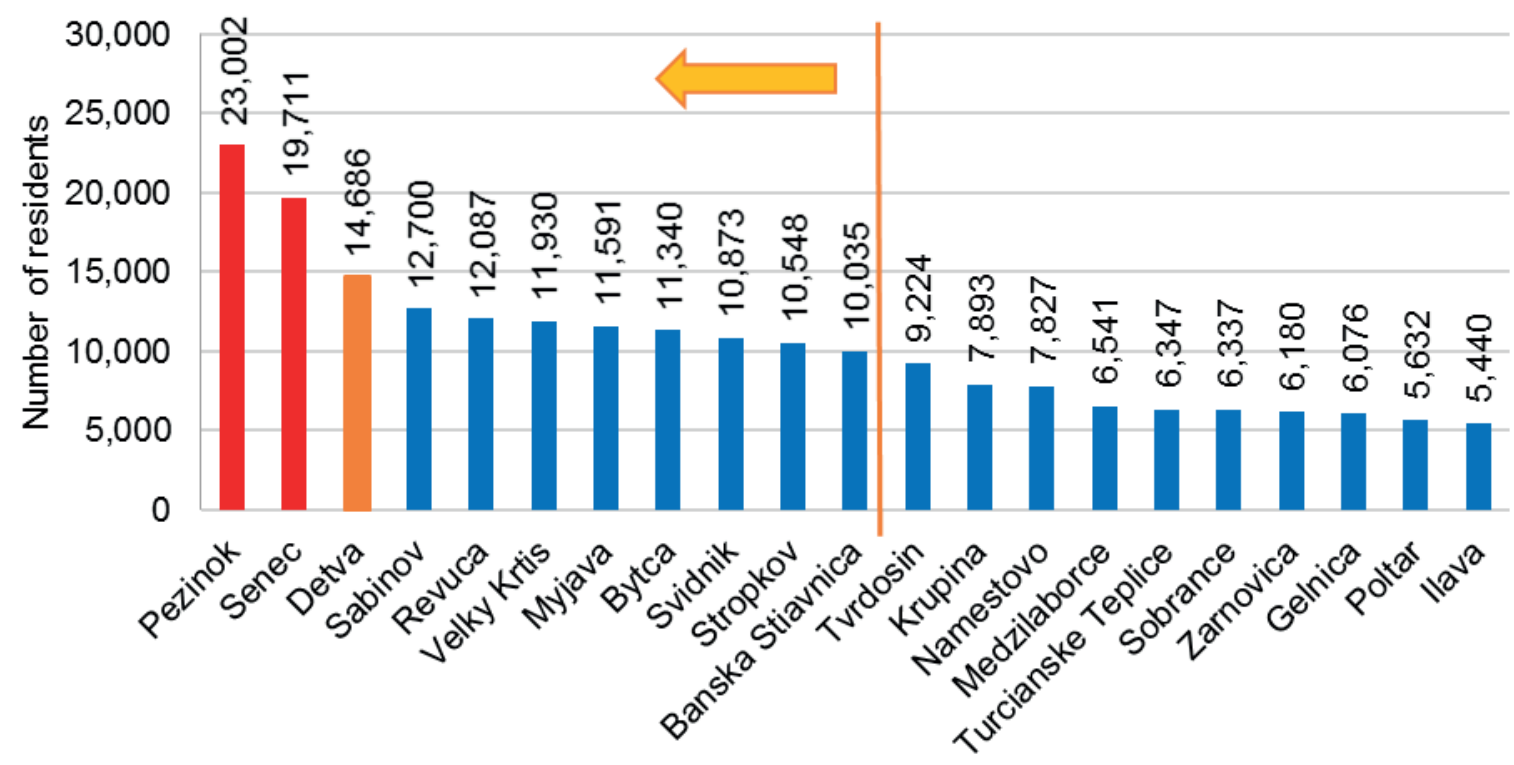

Figure 2 The number of residents of towns without the UPT operation, based on [7]

Table 1 Evaluation of facilities in towns without the UPT, [9-10]

\begin{tabular}{cccccc}
\hline & bus station & railway station & hospital & secondary school & university \\
\hline yes & 13 & 17 & 12 & 20 & 1 \\
no & 8 & 4 & 9 & 1 & 20 \\
\hline
\end{tabular}

However, it is necessary to note that building the UPT system is not affected only by the number of residents, but by many other factors, as well. Some additional factors are the town area or town residential area (built-up area), the fact if there is a bus or railway station in the town, if the town is a catchment area from the point of view of health services (a hospital in the territory of the town), as well as education (secondary schools and universities). Thus, one may assume some higher requirements to provide transport operation not only for town residents, but also for commuters. The need for the UPT in smaller towns and development of the integrated transport systems are dealt with by Nigro et al. [8]. Due to this reason, the need to build the UPT is justified even in towns with a smaller number of residents. Table 1 lists the results found for the investigated towns.
Analysis revealed that there is a railway station in Revuca and Velky Krtis, however, passenger transport is currently disrupted on the line. The highest number of secondary schools is in Svidnik (8), Banska Stiavnica (6), Pezinok, Revuca, Stropkov and Namestovo (4) and only in Ilava there is no secondary school. The university is situated only in Banska Stiavnica.

In the case of a foreign country, analysis was performed for Poland and part of the Czech Republic - for Moravia-Silesia region. Analysis of Poland implies that urban public transport is not operated in 77 towns (46\%), out of total 167 towns investigated. The number of residents in these towns is represented in Figure 3; in 13 towns the number of residents exceeds 15,000. In the case of Zawiercie, this value is exceeded several times. Regarding the town facilities, a railway station is 


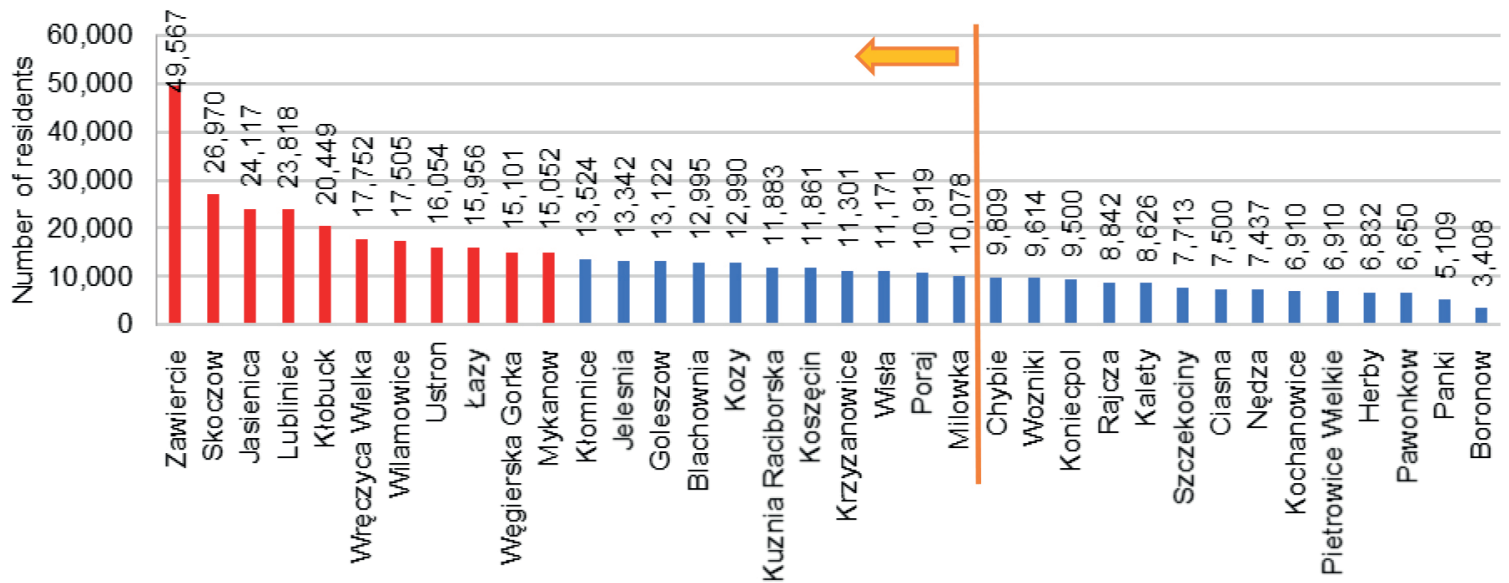

Figure 3 Number of residents of towns without the UPT operation in Poland, based on [11]

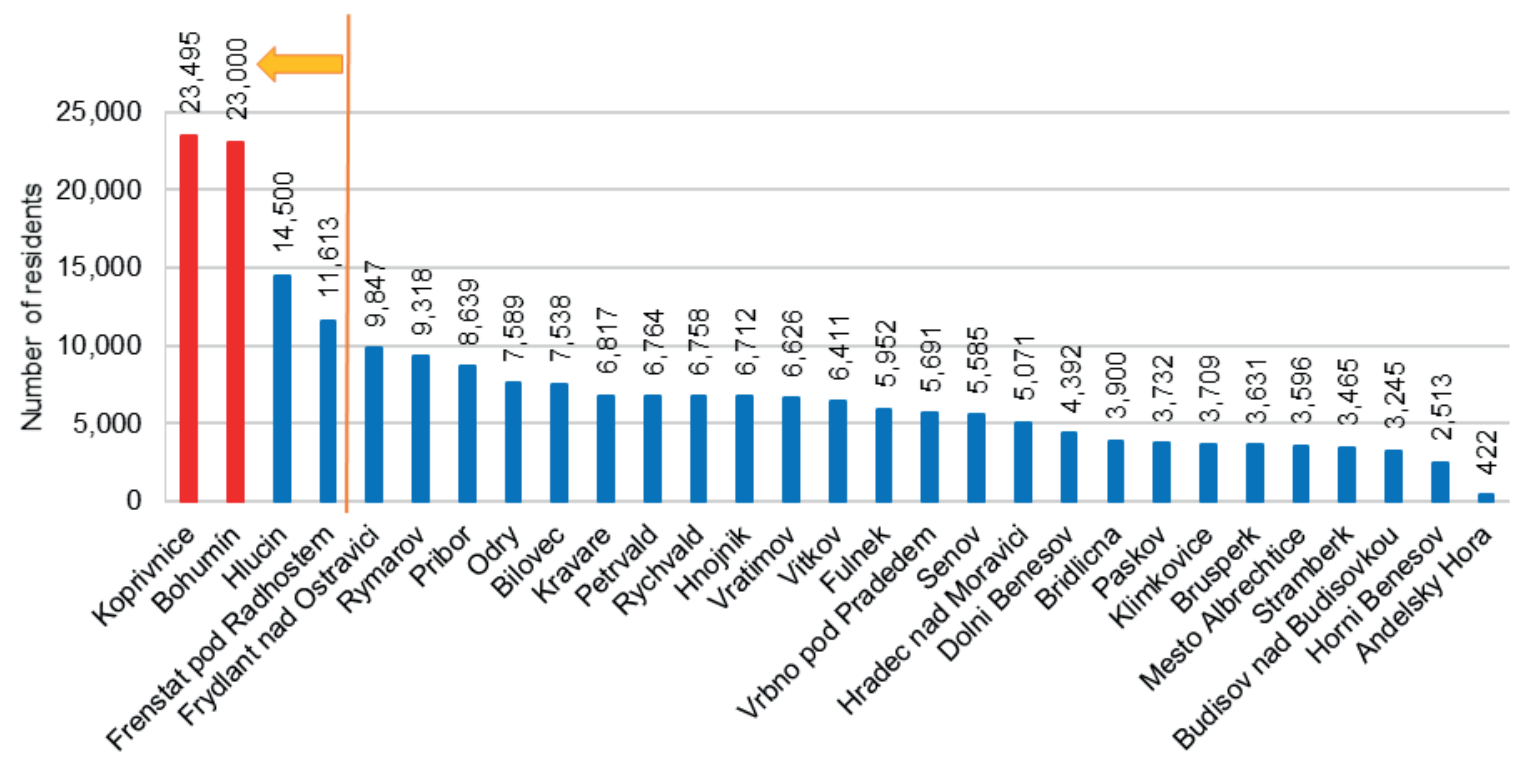

Figure 4 Number of residents in towns without the UPT operation in Moravia-Silesia region in the Czech Republic, based on [12]

situated in 29 towns, a hospital is situated only in 6 towns, secondary schools are in 31 towns and universities are not established in any of the evaluated towns without the UPT operation. The bus station facilities were not investigated in these towns.

In the case of analysis of the Moravia-Silesia region, it was found that the urban public transport is not operated in 29 towns, which represents $70 \%$, out of total 41 towns investigated. However, this is partially affected by the fact that the transport operation of multiple towns is performed by the suburban lines (a partial replacement of urban public transport), which are part of the integrated transport system ODIS (Integrated Transport System of MoraviaSilesia region). An overview of the number of residents of towns, where the UPT is not operated, is represented in Figure 4, which makes it clear that in 2 towns the number of residents exceeds the value of 20,000 .

Regarding the town facilities, a railway station is situated in 23 towns, hospital is situated in 4 towns, a secondary school exists in 13 towns and there is no university in any of the towns (with no UPT). The bus station facilities were not investigated in these towns.

\section{Methods of solution}

\subsection{The study of relation between the transport performances within the UPT and the gross domestic product in selected states of the EU}

The decision to study the relation between the transport performances of the UPT and the gross domestic product (GDP) was made by authors, because in the SR the UPT is operated in most of the towns where the UPT was funded through the national budget before 2003. In that year, the UPT was funded this way in 49 district towns; out of those towns, the UPT is currently not operated only in towns of Sabinov and Svidnik. To the contrary, in Piestany, Brezno and Skalica the UPT is operated even though it was not funded through the national budget in 2003. 
Table 2 Results of correlation between the transport performances in the UPT (passenger kilometres) and the GDP in selected EU states, Switzerland and Norway

\begin{tabular}{|c|c|c|c|c|c|c|c|c|}
\hline & country & $\begin{array}{l}\text { correlation } \\
\text { coefficient }\end{array}$ & $\begin{array}{c}\text { determination } \\
\text { coefficient }\end{array}$ & $\begin{array}{c}\text { coefficient } \\
a\end{array}$ & coefficient $b$ & P-value $a$ & P-value $X$ & $\begin{array}{c}\text { significance } \\
F\end{array}$ \\
\hline \multirow{4}{*}{$\begin{array}{c}\text { strong } \\
\text { direct } \\
\text { dependency }\end{array}$} & Switzerland & 0.9709 & 0.9989 & 0 & 0.0128 & $\mathrm{x}$ & 0.000 & 0.000 \\
\hline & Romania & 0.9421 & 0.9954 & 0 & 0.1015 & $\mathrm{x}$ & 0.000 & 0.000 \\
\hline & Macedonia & 0.9205 & 0.9426 & 0 & 0.2079 & $\mathrm{x}$ & 0.000 & 0.000 \\
\hline & Austria & 0.8702 & 0.9968 & 0 & 0.0333 & $\mathrm{x}$ & 0.000 & 0.000 \\
\hline \multirow{3}{*}{$\begin{array}{c}\text { moderate } \\
\text { direct } \\
\text { dependency }\end{array}$} & France & 0.7606 & 0.9847 & 0 & 0.0258 & $\mathrm{x}$ & 0.000 & 0.000 \\
\hline & Denmark & 0.5682 & 0.9598 & 0 & 0.0427 & $\mathrm{x}$ & 0.000 & 0.000 \\
\hline & Spain & 0.4091 & 0.9886 & 0 & 0.0500 & $\mathrm{x}$ & 0.000 & 0.000 \\
\hline \multirow{6}{*}{$\begin{array}{l}\text { weak direct } \\
\text { dependency }\end{array}$} & Croatia & 0.2469 & 0.9868 & 0 & 0.0825 & $\mathrm{x}$ & 0.000 & 0.000 \\
\hline & Poland & 0.2161 & 0.9415 & 0 & 0.1047 & $\mathrm{x}$ & 0.000 & 0.000 \\
\hline & Latvia & 0.1517 & 0.9552 & 0 & 0.1514 & $\mathrm{x}$ & 0.000 & 0.000 \\
\hline & Estonia & 0.0532 & 0.9387 & 0 & 0.1509 & $\mathrm{x}$ & 0.000 & 0.000 \\
\hline & Lithuania & 0.0289 & 0.9442 & 0 & 0.1053 & $\mathrm{x}$ & 0.000 & 0.000 \\
\hline & Finland & 0.0257 & 0.9916 & 0 & 0.0424 & $\mathrm{x}$ & 0.000 & 0.000 \\
\hline $\begin{array}{c}\text { weak } \\
\text { indirect } \\
\text { dependency }\end{array}$ & Bulgaria & -0.0949 & 0.9469 & 0 & 0.2853 & $\mathrm{x}$ & 0.000 & 0.000 \\
\hline \multirow{5}{*}{$\begin{array}{c}\text { moderate } \\
\text { indirect } \\
\text { dependency }\end{array}$} & $\begin{array}{c}\text { Czech } \\
\text { Republic }\end{array}$ & -0.3062 & 0.9699 & 0 & 0.1042 & $\mathrm{x}$ & 0.000 & 0.000 \\
\hline & Hungary & -0.4599 & 0.9777 & 0 & 0.1764 & $\mathrm{x}$ & 0.000 & 0.000 \\
\hline & Portugal & -0.5000 & 0.8921 & 0 & 0.0440 & $\mathrm{x}$ & 0.000 & 0.000 \\
\hline & Norway & -0.5344 & 0.9821 & 0 & 0.0133 & $\mathrm{x}$ & 0.000 & 0.000 \\
\hline & $\begin{array}{c}\text { Great } \\
\text { Britain }\end{array}$ & -0.7674 & 0.9680 & 0 & 0.0235 & $\mathrm{x}$ & 0.000 & 0.000 \\
\hline \multirow{4}{*}{$\begin{array}{c}\text { strong } \\
\text { indirect } \\
\text { dependency }\end{array}$} & Slovenia & -0.8110 & 0.9622 & 0 & 0.0953 & $\mathrm{x}$ & 0.000 & 0.000 \\
\hline & Netherlands & -0.9345 & 0.9445 & 0 & 0.0097 & $\mathrm{x}$ & 0.000 & 0.000 \\
\hline & Slovakia & -0.9384 & 0.7055 & 0 & 0.1120 & $\mathrm{x}$ & 0.000 & 0.000 \\
\hline & Sweden & -0.9795 & 0.9627 & 0 & 0.0239 & $\mathrm{x}$ & 0.000 & 0.000 \\
\hline
\end{tabular}

Towns of Bratislava, Banska Bystrica, Kosice, Presov and Zilina received subsidies for the urban public transport, which included regular, as well as capital expenditures. Other towns with the urban public transport received the so-called current transfers for the self-governing regions in order to provide regular public bus transport for the year 2003. Those transfers were intended to cover a decrease in incomes arising from the provision of discount travels and to provide the operation of the territory. At that time, the state also dictated the amounts of discounts for selected groups of passengers.

Since 2004, the direct subsidies from the national budget have been granted to urban public transport in Bratislava, Banska Bystrica, Kosice, Presov and Zilina, but there have been no subsidies for other urban public transports. The national budget, however, has found a subsidy for the selfgoverning regions to compensate for a loss, completely or partially, or to provide another compensation for carriers, while providing performances in public interest in regular public bus transport and to provide the operation of the territory. Since 2005, on the territory of the SR (and based on a change of responsibilities), funding of the UPT, determination of prices, as well as selection of a carrier, have lien within the full authority of towns. Towns or selfgoverning regions have been funding the UPT from current transfers from the national budget or their own incomes [13].

Hypothesis 01: If the gross domestic product increases, then the state tax revenues, as well as share of taxes for towns, increase, which should be manifested in support for the UPT and thus in an increase of the transport performances.

This hypothesis was verified on a sample of data on EUROSTAT from selected states of the European Union (EU), Switzerland and Norway, presented in Table 2, covering the years 1998-2017. The results of correlation between the transport performances in the UPT and the GDP, in selected EU states, are presented in Table 2.

In order to determine the intensity of correlation, the following criteria were established:

- weak dependency, if $0<|r|<0.3$,

- moderate strong dependency, if $0.3 \leq|r|<0.8$, 

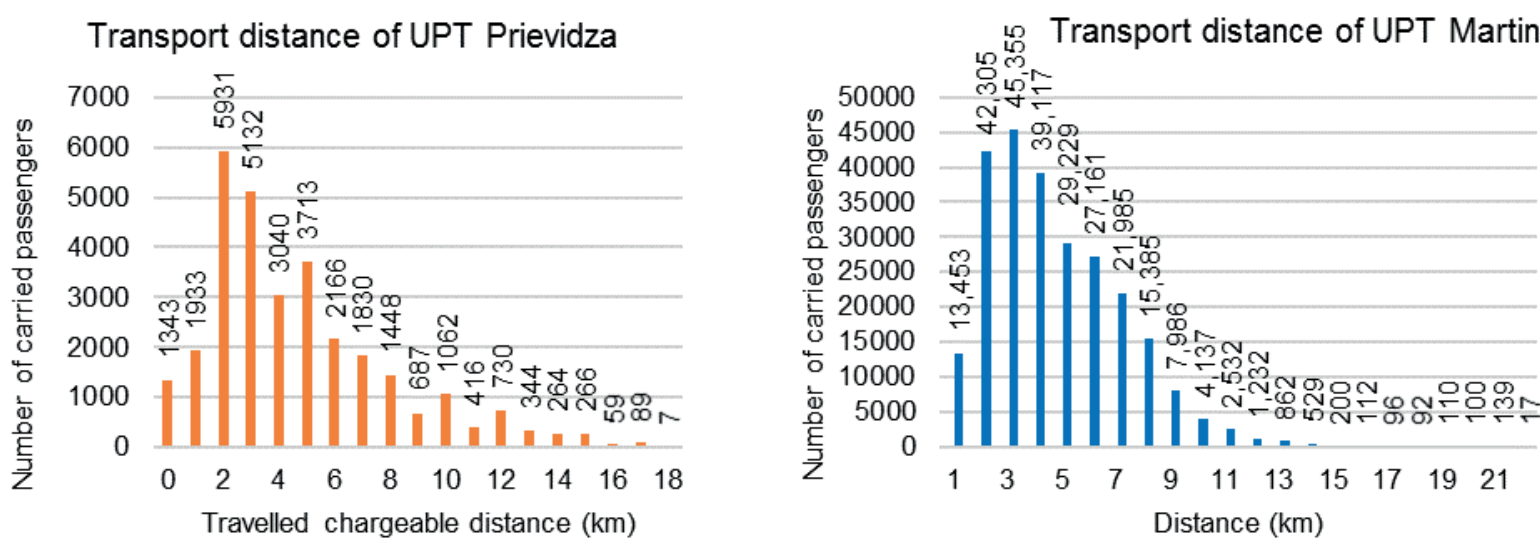

Figure 5 Distribution of the transport distance in the UPT Prievidza (left) and in the UPT Martin (right) in km, based on [14-15]

- $\quad$ strong dependency, if $0.8 \leq|r|<1$.

The studied dependency was modelled using a linear function in the form):

$y=a+b x$.

The significance level was selected at the level $\alpha=0.01$.

Initially, the linear regression model was created for each country. Based on the comparison of the significance level $\alpha=0.01$ to the P-value, it was determined that the localising constant $a$ was not significant in at least $75 \%$ of cases. Due to that, it was decided to create the linear regression models without a constant. Then, the form of a regression relation is as follows:

$y=b x$.

In analyses' results (Table 2), the individual states are sorted according to the correlation coefficients, starting from the strongest direct dependency to the strongest indirect dependency. Results imply that the GDP change impact on demand for the passenger transport by the UPT differs in the studied European countries.

The strong direct dependency is observed in Switzerland, Romania, Macedonia and Austria. France, Denmark and Spain fall into the category with the moderate strong direct dependency. The weak direct dependency can be seen in Croatia, Poland, Latvia, Estonia, Lithuania and Finland.

In the case of Bulgaria, the weak indirect dependency was discovered. The moderate indirect dependency is observed in the Czech Republic, Hungary, Portugal, Norway and Great Britain. Slovenia, Netherlands, Slovakia and Sweden feature the strong indirect dependency.

In the case of all the models, the significance level is less than 0.01, which means that all the models are significant. The results mentioned above indicate a different impact of the GDP on transport performances in the UPT. With respect to differences in the UPT funding, which is in majority of countries fully dependent on towns and their authorities, the transport performances in the UPT are also affected by regulation of individual automobile transport, employment rate, pricing policy, etc. Thus, the hypothesis 01 has not been confirmed.

\subsection{Selected experience from creating transport operation plans in UPT}

As a part of the towns' transport operation plans creation, one may state that not all the towns in the SR, which feature the UPT or urban bus transport, have worked out the transport operation plans. Effective as of April 2019, the Ministry of Transport and Construction of the SR imposed a fine from 500 Euro to 10,000 Euro upon a municipality (town) for failing to perform the obligation under the Article 20 Paragraph 4, Act No. 56/2012 Coll. on the road transport (preparation of the transport operation plan). If even after three months from the date of entry into force of the relevant decision on imposing the previous fine, the obligation were not performed, the fine would be imposed repeatedly until the obligation is performed. The transport operation plans are to be worked only for towns that already had the UPT. There are 21 district towns in the SR without the UPT. Do the residents of these towns not need UPT? Can they manage their mobility by foot, by bike or car? Do they have no problems with parking their cars in the town centres?

Even within district towns, the UPT is utilised for relatively long distances. For example, in the UPT Prievidza - Bojnice it was found that the majority of passengers travel for the distance of $2 \mathrm{~km}$, then the distances of 3.5 and $4 \mathrm{~km}$ follow (Figure 5). An average transport distance in Prievidza was discovered even at the level of $4.7 \mathrm{~km}$.

In the case of Martin, it was found that the highest number of passengers is transported for the distance of $3 \mathrm{~km}$; then follow the distances of 2,4 and $5 \mathrm{~km}$. The average transport distance was discovered at the level of $4.2 \mathrm{~km}$.

Another criterion is the spatial accessibility of the public passenger transport. As part of working the transport operation plans out, one always assesses distribution of the UPT stops, as well as stops of the suburban bus transport 


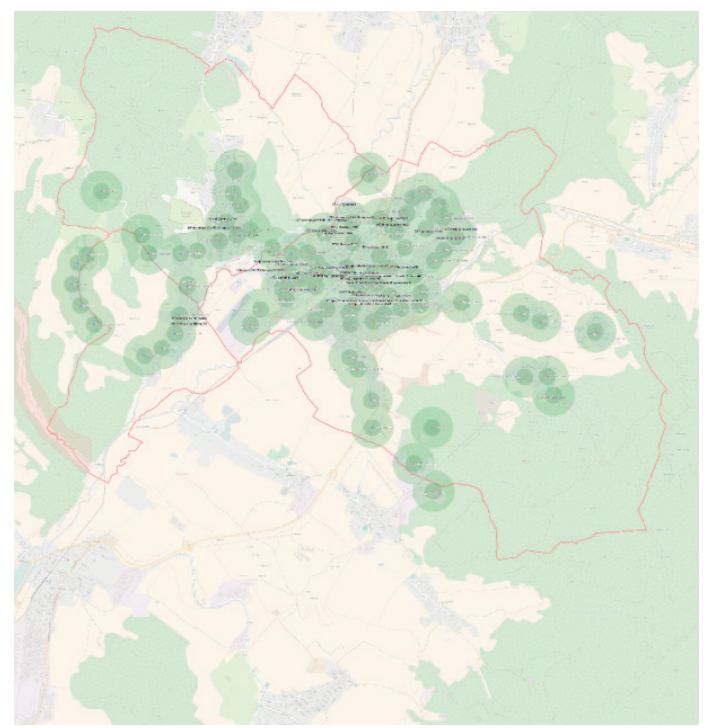

Figure 6 Representation of isochrones of the stops accessibility in the UPT Prievidza - Bojnice and village Opatovce nad Nitrou and accessibility of schools, based on [14]

Legend: Dark green circle of UPT The stop accessibility less than 2 min. by foot Light green circle of UPT The stop accessibility less than 5 min. by foot
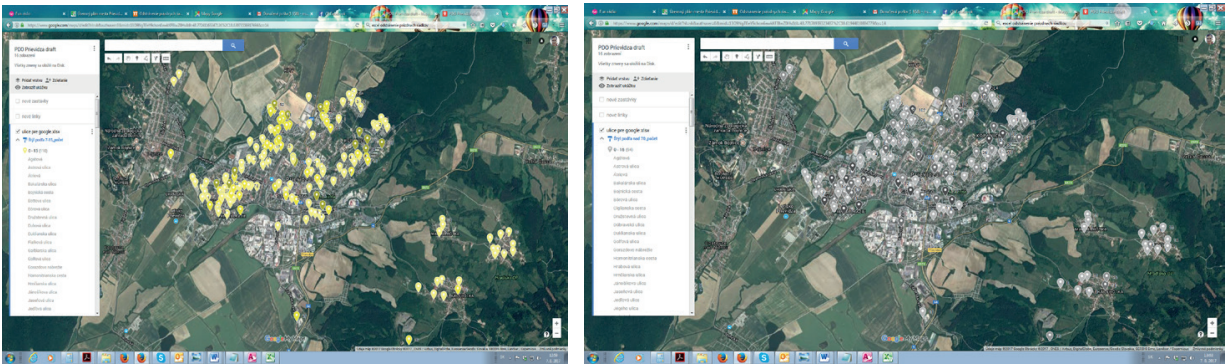

Figure 7 The graphical representation of streets with an above-average number of residents at the age of 7 -15 years (left) and at the age above 70 years (right) in towns of Prievidza and Bojnice; a darker colour means a higher number, based on [14]

and railway transport on the territory of the given town and their accessibility from the built-up area [14-15]. The spatial accessibility of the UPT is evaluated through depicting the isochrones of the time accessibility for individual stops, which, at the same time, will evaluate the area operation of the town. Places without the UPT operation are defined, as well (Figure 6). It is not possible to expect that the suburban bus transport lines, with very small area coverage of stops, would suffice for commuting to schools (children), or to health care institutions, or that citizens would commute to and from the stops for the distance of $1.5-2 \mathrm{~km}$.

The passengers require an attendance distance to the UPT stop (the so-called spatial accessibility of the UPT), which is derived from conducted questionnaire surveys within the management of transport operation plans; in the town of Prievidza it was discovered at the level of $300 \mathrm{~m}$ (71.6\% of responses) [14].

Since not all the residents of the town or commuters (especially schoolchildren and pensioners above 70) are given the option to get to their destination in the town using other transport means than the UPT, the transport operation plans also include a study of the town residents' distribution from the point of view of the age structure by individual streets (Figure 7). The routing of lines and the time position of individual connections can then reflect requirements of the residents with a higher share in the given urban part.

A detailed study of the access by foot, including the quality of pavement surface, to the UPT stops was conducted in Ljubljana, Slovenia [16]. Modelling of the UPT stops accessibility in smaller towns is in the centre of interest of Lamotte, O. et al. [17]. They state that in Europe and France it is basically anticipated that residents are close to a UPT stop if its distance is not more than $400 \mathrm{~m}$ [17]. This statement was also confirmed by results of research realised in the Slovak Republic. In addition, thanks to studying different towns, especially in South Korea, a multi-criterial analysis was worked out, which also considers deploying the advanced public transport modes (APTM) with respect to building the new types of towns, [7].

Figure 8 implies that the pedestrian traffic is only counted with for the distance of up to $1 \mathrm{~km}$; in the case of the bike transport, it is something more than $2 \mathrm{~km}$. Still, the utilisation of the bus transport with a combination of accelerated lines is counted with. One can see that foreign 


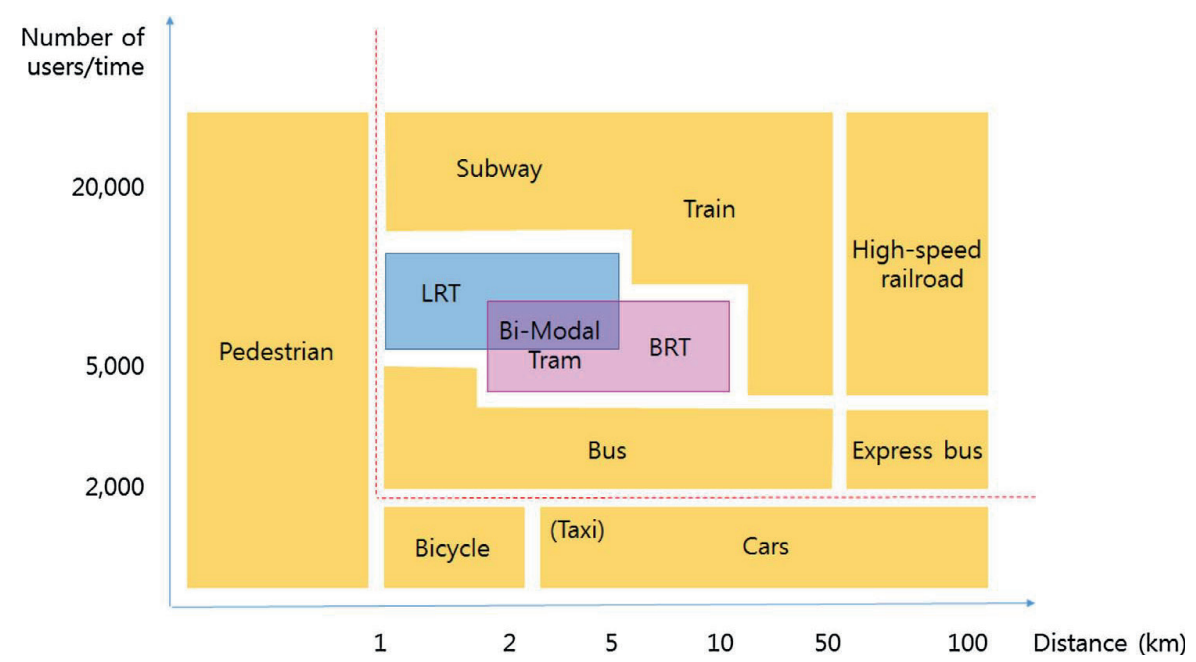

Figure 8 Characteristics of the advanced public transport modes (APTM) and existing options for the transport modes, [7]

countries deal in detail with the question what kinds of public passenger transport should be applied in towns. In the SR, part of residents from bigger towns, with respect to the growing prices of flats and a lack of building lands, moves to the countryside where the satellite built-up areas of family houses and flat complexes arise without sufficient facilities of schools and health care institutions, etc. and often even without a link to the public passenger transport [18].

\section{Application of the multi-criterial analysis and discussion}

As a part of the decisions making about the need to provide the UPT, it is necessary to take into account many more factors than the number of the town residents only. The authors studied a whole series of other factors besides those already mentioned. In fact, it is a problem of a multicriterial decision making which is also applied to logistics [19].

In case of a multi-criterial decision-making, the decisive subject evaluates individual variants through the multiple criteria when the objectification of the decision process depends on a number of evaluative aspects. If the number of evaluative criteria and variants is small, the decisive subject can make the decision based on their intuition. However, if the number of criteria is higher and the decision situation is more complex, it is necessary to apply formalised procedures. An appropriate formalised procedure is determination of the evaluative criteria weights and aggregation of the partial evaluations into a complex evaluation [20]. Fiala, Jablonsky and Manas [21] introduce that in case of the multi-criterial evaluation of variants the task is specified explicitly with a set of alternatives $\mathrm{A}=\{\mathrm{a} 1$, a2..., etc.\}. In here presented case, it is created with options to choose a transport means and maybe specific carriers and with a set of evaluative criteria $F=\{f 1, f 2 \ldots, f k\}$, which is created with selected bank products and with evaluation of selected variants via individual criteria in the form of the so-called criteria matrix:

$$
\begin{aligned}
& \begin{array}{llll}
f_{1} & f_{2} & . & .
\end{array} f_{k} \\
& a_{1}\left[\begin{array}{llll}
y_{11} & y_{12} & \ldots & y_{1 k}
\end{array}\right. \\
& a_{2} \quad \begin{array}{llll}
y_{21} & y_{22} & \cdots & y_{2 k}
\end{array} \\
& \text {. . . . } \\
& \text {. } . . . . \\
& a_{p}\left[\begin{array}{llll}
y_{p 1} & y_{p 2} & . & y_{p k}
\end{array}\right]
\end{aligned}
$$

Elements of the criteria matrix, $y_{i j}, i=1,2 \ldots, p, j=1$, $2 \ldots, \mathrm{k}$, express information on evaluation of alternatives by individual criteria. The information may take the following form:

- cardinal information - it represents the actual value achieved with individual variants during the evaluation by the given criteria,

- ordinal information - it expresses the order of a certain variant by individual criteria, i.e. sorting the criteria by their importance,

- relative information - it compares pair variants between each other by individual criteria [21].

The next criterion of the decision-making about the UPT provision is reduction of the attendance distance by foot or by the bike transport to the railway or bus station and thus reduction of individual automobile transport effects on environment in the town, reduction of congestions, enhancement of road transport safety, etc. [22]. Moreover, it is very important to study how the behaviour of residents in smaller towns is affected by quality of the UPT. A factor analysis can be applied here [23].

Furthermore, a very important issue is the setting of the UPT offering via lines, connections and operation time [24]. They are bound to provide accessibility of the UPT to health care institutions, schools, offices and last, but not the least, regular commuting to work. Provision of transport to work is a separate specific area of studying the mobility of the population.

Based on the assessments conducted by the authors, eight criteria to be taken into account when deciding on the necessity of establishing the UPT were defined. Standardized scales of importance and reference values were defined for individual criteria (Table 3). The ranking method was used to determine the scales of importance, 
Table 3 Defined criteria with assigned scales of importance and reference values

\begin{tabular}{lcc}
\hline criteria & scales of importance & reference values \\
\hline number of inhabitants & 0.22 & 0.19 \\
number of pupils and students of all the schools & 0.17 & 50,000 \\
number of employers with 100 or more employees & 0.14 & 10 \\
number of medical facilities (ambulances / wards in the hospital) & 0.11 & 100 \\
number of public authorities (district office, building office, labour office, etc.) & 0.08 & 50 \\
railway station equipment (number of passenger rail connections) & 0.06 & 100 \\
bus station equipment (number of bus connections) & 0.03 \\
preference for ecological modes of transport & 500 \\
\hline
\end{tabular}

*In the case of medical facilities of superregional importance, value of the scales of importance needs to be adjusted

Table 4 Application of the methodical procedure

\begin{tabular}{clcc}
\hline & information's of the city under assessment & fulfilment of the criterion [\%] & achieved evaluation \\
\hline 30,000 & inhabitants & 60 & 75 \\
1,500 & pupils and students & 30 & 13.2 \\
3 & employers with 100 or more employees & 30 & 5.1 \\
30 & ambulances / wards in the hospital & 20 & 4.2 \\
10 & public authorities & 21 & 2.2 \\
21 & passenger rail connections & 26 & 1.68 \\
130 & bus connections & 1.56 \\
1 & the city wants to prefer an ecological mode of transport & & 3 \\
\hline total & & & 45.19 \\
minimum value for ordering the UPT & & no \\
necessary UPT & & \\
\hline
\end{tabular}

where the order of the criteria was ranked by the authors based on their experience with the creation of transport operation plans. Defined reference values for each criterion take into account the fact that the methodology is proposed for small towns, where values were determined by expert authors estimate. Determination of the precise reference values will be the subject of further more detailed research.

The methodological procedure is based on the percentage assessment of fulfilment of the defined criteria reference values. The achieved evaluation of the criteria corresponds to the value of the performance multiplied by the scales of importance for the given criterion. The sum of the subtotal is determined final value, whereby it is possible to decide on the need for setting up the UPT. The authors set the minimum value of the final evaluation at the level of 60 points, which corresponds to fulfilment of the reference values at the level of $60 \%$. An example of application of the methodological procedure is given in Table 4.

The decision-making also includes the criterion weight of impacts of a specific transport mode, or a combination of transport means on the environment. Except for the costs, the so-called carbon footprint on specific transport means used may be calculated [25]. Alternatively, in the case of railway passenger transport, which uses the electricity as its source of energy, calculation of the so-called indirect emissions, which arise during its production, will be taken into account [26-27].
As a part of the further research, the authors would like to focus on completing the methodology for application of the multi-criterial analysis to the decision process on providing the UPT in smaller towns with less than 50,000 or 30,000 residents. The objective is its application in the SR and Poland, the Czech Republic and some other EU states, using experts on the UPT.

In this case, the Delphi method was used to verify the correctness of the established criteria and defined the scales of importance and it is assumed to verify the accuracy of the defined methodology, as well.

\section{Conclusion}

In the case of important strategic decisions on provision of the UPT and its scope, the following strategic documents should definitely be helpful in the SR: a transport operation plan of a town, or a transport operation plan of a self-governing region; here the methods of a multicriterial decision making are required to be applied. It is recommended that the decisive subject - a town or a selfgoverning region - evaluates individual variants using the multiple criteria, when the objectification of the decision process depends on a number of evaluative aspects and on the accuracy of inputs, e.g. from transport operation plans, which, unfortunately, are still worked out in a varied quality. 
For the decision process on provision of the UPT and choice of the transport means, one may also utilise the latest decision techniques and potential engineer applications, which can evaluate a whole series of data obtained online within a transport chain; e.g. Collaborative Filtering Bandits method can be applied here [28-29]. In the case of the multi-criterial analysis application, it is possible to complete the partial evaluation by using other additional and new methods [30].

Of course, it is inevitable to deal with requirements of the town residents, visitors, students, etc. imposed on the urban public transport in view of building a sustainable transport system in the town [31-32].

In the Slovak Republic, the general legislation was amended with a regulation of the Ministry of Transport and Construction of the SR No. 5/2020 Coll., laying down certain provisions related to ordering of the public passenger transport. In addition, it includes standards of transport operation. Under this regulation, special standards for urban transport in municipalities, with the number of residents less than 50,000, are represented by creation of connections, leading mainly to the centres with the occurrence of jobs, schools, health care institutions and public authorities. That includes guaranteed changes, bound to the suburban or long-distance transport to facilities mentioned before, if such centres are at a distances of more than $1,500 \mathrm{~m}$ or more than 20 min walk from a stop of the long-distance or suburban transport. Part of the transport operation of a village or a town may also be alternative transport in the form of a hybrid operation of suburban lines with the character of an intra-municipal operation in the territory of a village or town.

Unfortunately, with respect to saving money, such standards set for towns with less than 50,000 residents may lead to the point when, in certain district towns of the SR, the offering of the UPT connections, as well as the spatial accessibility of stops may decrease, especially if the suburban lines are funded by the self-governing region, not the town itself.

As a part of the UPT funding, it is necessary to highlight that the issue does not lie only in the mobility of town residents, but in the financing of an environmentally more friendly form of mobility than a car is, as well. In other words, the subject under consideration is financing a healthier way of life of town residents.

Potential considerations regarding the possibility to replace the UPT by a car sharing in smaller towns, where also the offering of taxi service is not sufficient, are published in [33].

\section{Acknowledgement}

The paper was created within the project of an institutional research of the Faculty of Operation and Economics of Transport and Communications No. 7/ PEDAS/2019 Plans and Standards of Transport Operation of Towns and Regions as Part of Transport Operation Plans.

\section{References}

[1] STANKOVIC, M., GLADOVIC, P., POPOVIC, V., LUKOVAC. V. Selection criteria and assessment of the impact of traffic accessibility on the development of suburbs. Sustainability. [online]. 2018, 10(6), 1997 [accessed 2019-6-10]. ISSN 2071-1050. Available from: https://doi.org/10.3390/su10061977

[2] DYDKOWSKI, G. Urban transport integration (in Polish). Katowice: Wydawnictwo Uniwersytetu Ekonomicznego w Katowicach, 2009. ISBN 978-83-7246-452-1.

[3] POLIAK, M., MRNIKOVA, M., JASKIEWICZ, M., JURECKI, R., KACIAKOVA, B. Public transport integration. Communications - Scientific Letters of the University of Zilina. [online]. 2017, 19(2), p. 127-132 [accessed 2019-610]. ISSN 1335-4205, eISSN 2585-7878. Available from: http://komunikacie.uniza.sk/index.php/communications/article/ view/196

[4] TOMANEK, R. Effectiveness of free of charge public transport in cities (in Polish). Public Transport [online]. 2017, 69(4), p. 18-25 [accessed 2019-6-10]. ISSN 1429-5788, eISSN 2543-6570. Available from: http://komunikacja.kzkgop.com. pl/public_media/fb/files/czasopisma/komunikacja/2017/kp_04_2017_ENG.PDF

[5] SUROVEC, P. Design of the urban public transport system. 1. ed. Zilina: EDIS - Publishing house of University of Zilina, 1999. ISBN 80-7100-586-X.

[6] CIBULKA, J.: The increase in transport relations satisfied by traffic that are carried out to work only inside the city territory as a result of increasing distance between home and work. Development of transport with respect to the environment. Usti nad Labem. 1979.

[7] LEE, D. J. A multi criteria approach for prioritizing advanced public transport modes (APTM) considering urban types in Korea. Transport Research [online]. 2018, A111, p. 148-161 [accessed 2019-6-10]. ISSN 0965-8564. Available from: https://doi.org/10.1016/j.tra.2018.02.005

[8] NIGRO, A., BERTOLINI, L., MOCCIA, F. D. Land use and public transport integration in small cities and towns: assessment methodology and application. Journal of Transport Geography [online]. 2019. 74, p. 110-124 [accessed 2019-6-10]. ISSN 0966-6923. Available from: https://doi.org/10.1016/j.jtrangeo.2018.11.004

[9] Statistical Office of the Slovak Republic [online] [accessed 2019-06-10]. Available from: www.datacube.statistics.sk 
[10] The network of school and school facilities in the Slovak Republic - The Ministry of Education, Science, Research and Sport of the Slovak Republic [online] [accessed 2019-06-10]. Available from: www.minedu.sk

[11] Local Data Bank [online] [accessed 2019-05-25]. Available from: https://bdl.stat.gov.pl/BDL

[12] The Czech Statistical Office [online] [accessed 2020-01-15]. Available from: https://www.czso.cz/csu/czso/databazedemografickych-udaju-za-obce-cr

[13] KONECNY, V., GNAP, J., SIMKOVA, I. Impact of fiscal decentralization on motor vehicle taxation in the Slovak republic. Transport and Telecommunication Journal [online]. 2016, 17(1), p. 28-39 [accessed 2019-6-10]. ISSN 1407-6179. Available from: https://doi.org/10.1515/ttj-2016-0004

[14] GNAP, J., GOGOLA, M., POLIAK, M., KONECNY, V., MAJER, T., CERNICKY, L., KUPCULJAKOVA, J., PALO, J., VARJAN, P., BEREZNY, R. Transport operation plan of the city of Prievidza - optimal variant [online]. University of Zilina, 2017 [accessed 2019-05-25] Available from: http://www.prievidza.sk/upload/wsw/files/file/SAMOSPRAVA/MsZ/PDO\%20 Prievidza\%20FIN.pdf

[15] GNAP, J., GOGOLA, M., POLIAK, M., KONECNY, V., MAJER, T., CERNICKY, L., KUPCULJAKOVA, J., PALO, J., SLAVIK, R., SETTEY, T. Transport operation plan of the city of Martin. University of Zilina, 2019.

[16] TIRAN, J., LAKNER, M., DROBNE, S. Modelling walking accessibility: a case study of Ljubljana, Slovenia. Moravian Geographical Reports [online]. 2019, 27(4), p. 194-206 [accessed 2019-6-10]. ISSN 2199-6202. Available from: https://doi.org/10.2478/mgr-2019-0015

[17] LAMOTTE, O., GAUD, N., GALLAND, S. Towards the dynamic evaluation of a public bus network for small size urban environments. Procedia Computer Science [online]. 2015, 56, p. 168-176 [accessed 2019-6-10]. ISSN 1877-0509. Available from: https://doi.org/10.1016/j.procs.2015.07.191

[18] GOGOLA, M., HOCOVA, M. Deurbanisation and mobility. Transportation Research Procedia [online]. 2016, 14, p. 1193-1200 [accessed 2019-6-10]. ISSN 2352-1465. Available from: https://doi.org/10.1016/j.trpro.2016.05.190

[19] LEBEAU, O., MACHARIS, C., VAN MIERLO, J., JANJEVIC, M. Improving policy support in city logistics: the contributions of a multi-actor multi-criteria analysis. Case Studies of Transport Policy [online]. 2018, 6(4), p. 554-563 [accessed 2019-6-10]. ISSN 2213-624X. Available from: http://dx.doi.org/10.1016/j.cstp.2018.07.003

[20] REPISKY, J. Decision theory. 2. ed. Nitra: Slovak University of Agriculture in Nitra, 2005. ISBN 80-8069-475-3.

[21] FIALA, P., JABLONSKY, J., MANAS, M. Multi-criterial decision making. 1. ed. Prague: University of Economics, 1994. ISBN 80- 7079-748-7.

[22] KALASOVA, A., KUBIKOVA, S, MIKULSKI, J. The impact of intelligent transport systems on an accident rate of the chosen part of road communication network in the Slovak republic. Communications in Computer and Information Science [online]. 2016, 640, p. 47-58 [accessed 2019-6-10]. ISSN 1865-0929. Available from: https://doi.org/10.1007/978-3319-49646-7_5

[23] CHEBA, K., SANIUK, S. Urban mobility - identification, measurement and evaluation. Transport Research Procedia [online]. 2016, 14, p. 1230-1239 [accessed 2019-6-10]. ISSN 2352-1456. Available from: https://doi.org/10.1016/j. trpro.2016.05.194

[24] GNAP, J., KONECNY, V., POLIAK, M. Demand elasticity of public. Journal of Economics [online]. 2006, 54(7), p. 668-684 [accessed 2019-6-10]. ISSN 0013-3035. Available from: https://www.researchgate.net/publication/292548426_Demand_ elasticity_of_public_transport

[25] PETRO, F., KONECNY, V. Calculation of emissions from transport services and their use for the internalisation of external costs in road. Procedia Engineering [online]. 2017, 192, p. 677-682 [accessed 2019-6-10]. ISSN 1877-7058. Available from: https://doi.org/10.1016/j.proeng.2017.06.117

[26] SKRUCANY, T., KENDRA, M., SARKAN, B., GNAP, J. Software simulation of an energy consumption and GHG production in transport. Tools of transport telematics. Communications in Computer and Information Science [online]. 2015, 531, p. 151-160 [accessed 2019-6-10]. ISSN 1865-0929. Available from: https://doi.org/10.1007/978-3-31924577-5_15

[27] SKRUCANY, T., GNAP, J. Energy intensity and greenhouse gases production of the road and rail cargo transport using a software to simulate the energy consumption of a train. In: 14th Transport Systems Telematics Conference TST 2014: proceedings. Vol. 471. Berlin: Springer-Verlag, 2014. ISSN 1865-0929, p 263-272.

[28] LI, S., KARATZOGLOU, A., GENTILE, C. Collaborative filtering bandits. In: 39th ACM SIGIR Conference of Research and Development in Information Retrieval: proceedings. New York: NY, United States: Association for Computing Machinery, 2016. ISBN 978-1-4503-4069-4, p. 539-548.

[29] BOUNEFFOUF, D. Contextual bandit algorithm for risk-aware recommender systems. In: IEEE Congress on Evolutionary Computation CEC held as part of IEEE World Congress on Computational Intelligence IEEE WCCI: proceedings. 2016. p. 4667-4674.

[30] HAO, F., LI; S., MIN, G., KIM, H.-CH., YAU, S. S., YANG, L. T. An efficient approach to generating location-sensitive recommendations in ad-hoc social network environments. IEEE Transactions on Services Computing [online]. 2015, 8(3), p. 520-533 [accessed 2019-06-10]. Available from: https://doi.org/10.1109/TSC.2014.2401833 
[31] MASOUMI, H. A discrete choice analysis of transport mode choice causality and perceived barriers of sustainable mobility in the MENA region. Transport Policy [online]. 2019, 79, p. 37-53 [accessed 2019-8-1]. ISSN 0967-070X. Available from: https://doi.org/10.1016/j.tranpol.2019.04.005

[32] GNAP, J., KONECNY, V. Transport policy related to road transport and sustainable development. Communications Scientific Letters of the University of Zilina [online]. 2003, 5(1), p. 52-61 [accessed 2019-6-10]. ISSN 1335-4205, eISSN 2585-7878. Available from: http://www3.uniza.sk/komunikacie/archiv/2003/1/1_2003en.pdf

[33] ROTARIS, L., DANIELIS, R. The role for car sharing in medium to small-sized towns and in less densely populated rural areas. Transport Research [online]. 2018, A115, p. 148-161 [accessed 2019-6-10]. ISSN 0965-8564. Available from: https://doi. org/10.1016/j.tra.2017.07.006 